Ann. Biol. anim. Bioch. Biophys., 1979, 19 (1 B), 135-150

\title{
Effect of intra-uterine growth retardation on cellular proliferation and differentiation in developing rat
}

\author{
par Jeanne-Marie ROUX, Claude CHANEZ-BEL, Catherine DEGREMONT, Anne- \\ Marie GABEN-COGNEVILLE, Marie-Claude FULCHIGNONI-LATAUD, Elisa- \\ beth SWIERCZEWSKI, Claude TORDET-CARIDROIT, A. MINKOWSKI
}

Unité I.N.S.E.R.M. 29, Hôpital Port-Royal,

123, boulevard de Port-Royal, 75014 Paris, France.

Summary. Intra-uterine growth retardation was induced in the rat by clamping the uterine artery on day 17 of gestation. It was shown that decreased weight of the body and of certain organs depended solely on a reduction in cell number. However, in brown adipose tissue both cell number and cell size were modified. In each organ studied the changes observed in DNA thymidine incorporation were in good correlation with the variation of DNA accumulation and the growth rate. Some biochemical differentiation processes were studied in the liver (key enzymes of gluconeogenesis, glycolysis and detoxification), the cerebrum (lipidic composition related to myelinisation) and the BAT (mitochondrial proteins, lipids, glycerokinase). Enzymes and responsiveness to hormonal stimuli appeared normally, but sometimes smaller amounts of enzyme were synthesized. A strikingly persistent feature was that brain weight and cell number remained nearly unchanged.

\section{Introduction.}

Different factors such as endocrine or genetic anomalies, the effects of certain drugs, haemodynamic or nutritional alterations may modify the development of the foetus during gestation. Numerous papers and reviews have analyzed the different origins of hypotrophy, and they will therefore not be discussed in this report (ChanezBel, 1972 ; Winick, 1974 ; Andrews, 1970).

As the mother of a human hypotrophic baby often presents an anomalous uteroplacental flow, our group was primarily concerned with studying experimental hypotrophy induced by restriction of blood flow during gestation. We chose the rat as experimental material for studies on intra-uterine growth retardation. Wigglesworth's method was used (1964) which consists in ligating the artery and vein of one of the uterine horns on day 17 of gestation. With this method it is possible to obtain a reduction of up to $50 \mathrm{p} .100$ of average foetal weight as shown on a standard reference graph (Chanez-Bel, 1972). 
We consider as hypotrophic or IUGR * an animal showing a weight reduction equal to or greater than 30 p. 100 as compared with the control of the same age. This figure is twice that of the standard deviation from the average weight of normal animals.

The following report is an analysis of the results obtained in recent years by the group working on this experimental model.

\section{I. - Somatic development.}

Body growth (Chanez-Bel, 1972 ; Tordet-Caridroit et al., 1969). - A comparative study of IUGR and control rats enabled us to analyze the effects of blood flow restriction in utero on their growth. From the day after ligature (day 18 cf pregnancy) the IUGR foefuses showed a 20 p. 100 weight reduction. This percentage increased steadily until birth when it reached an average of 38 p. 100.

At birth the newborn were grouped into litters of six composed of normal and hypotrophic animals. The weight difference between the two groups increased, reaching a maximum at 5 days (44 p. 100). These are average figures, for reductions of up to 78 p. 100 of the average foetal weight were recorded.

This difference in body weight persisted to adulthood and the IUGR rats never reached the weight of the control rats whatever the rearing conditions (Chanez-Bel 1972).

Organ growth (fig. 1). - Twelve hours before birth the foetus showed a considerable reduction of all organs, particularly of the liver and brown adipose tissue. The brain however was relatively unchanged, its weight being reduced by only about

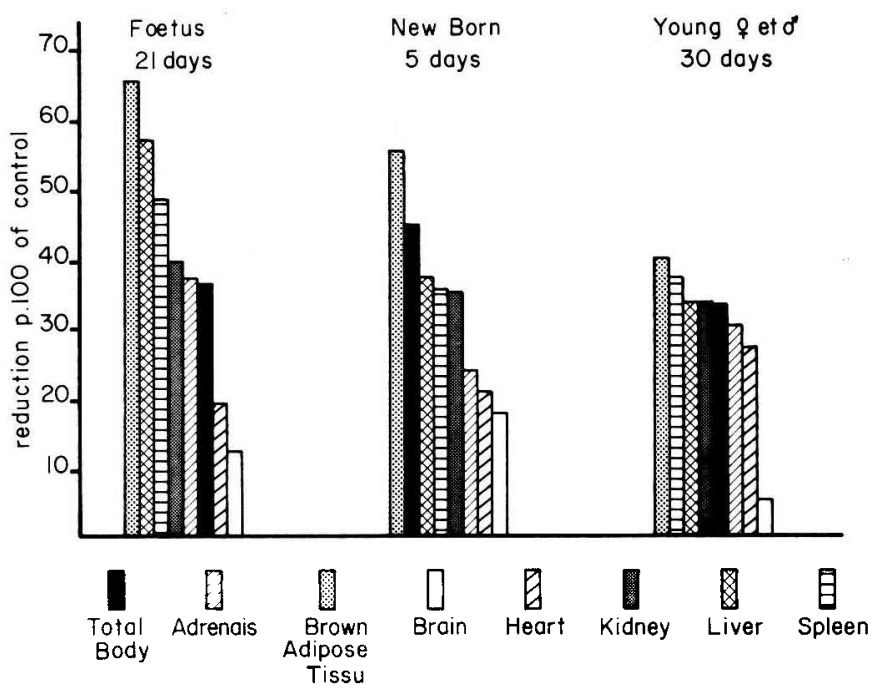

FIG. 1. - Effect of intra-uterine growth retardation on total body weight and on the weight of various organs ( $p .100$ reduction of control).

* IUGR $=$ Intra-Uterine Growth Retardation. 
10 p. 100 . The cerebellum is a special case, as development and differentiation take place after birth. Multiplication of the Purkinje cells starts only at the postnatal period and reaches a maximum on day 6 ; at this stage the cerebellum showed a highly significant weight retardation which persisted right up to the end of our study (26 days) (table 1). At weaning the average reduction of the organs leveled off at about 30 p. 100 and remained that way until the animals were killed. Cerebral weight remained similar to that of the control rats.

TABLE 1

Weight of cerebellum during development in IUGR and control rats

\begin{tabular}{|c|c|c|c|c|c|c|c|}
\hline Age & 5 days & 6 days & 7 days & 9 days & 12 days & 21 days & 26 days \\
\hline Control & $\begin{array}{l}36.66 \\
\pm 1.85\end{array}$ & $\begin{array}{c}44.50 \\
+2.18\end{array}$ & $\begin{array}{c}56.80 \\
\pm 1.65\end{array}$ & $\begin{array}{l}73.00 \\
\pm 3.24\end{array}$ & $\begin{array}{r}102.30 \\
\pm \quad 5.22\end{array}$ & $\begin{array}{r}132.57 \\
\pm 8.47\end{array}$ & $\begin{array}{r}169.24 \\
\pm 7.04\end{array}$ \\
\hline IUGR & $\begin{array}{c}29.33 \\
\pm 1.76\end{array}$ & $\begin{array}{c}35.58 * * \\
\pm 1.39\end{array}$ & $\begin{array}{l}45.00 * * \\
\pm 2.36\end{array}$ & $\begin{array}{l}63.00 * \\
\pm 1.48\end{array}$ & $\begin{array}{c}76.86 * * \\
\pm 3.83\end{array}$ & $\begin{array}{c}119.61 * \\
\pm 4.02\end{array}$ & $\begin{array}{c}138.69 * * \\
\pm 7.17\end{array}$ \\
\hline
\end{tabular}

* Significant $(p \leqslant 5) ; * *$ Significant $(p \leqslant 1$ p. 100) ; \pm Standard deviation.

\section{II. - Cell number and division.}

A study of the growth and chemical composition of certain organs showed (Roux ef al., 1970 ; Cogneville, 1973) the following :

- brain : no significant change in weight or chemical composition ;

- liver : weight decrease with no change in tissue composition ;

- brown adipose tissue : weight decrease accompanied by modified composition.

These results confirmed that intra-uterine growth retardation may have different effects depending upon the organ. It has been shown that an important decrease in organ weight may be the result of a decrease in cell number and/or size.

A) Cell number (Roux, 1971 $a$ et $b$ ). - In general the total DNA content of an organ was used to estimate the number of nuclei and hence the number of cells, the ratio wet weight/DNA gave an estimation of the size of the cells, and the ratio protein/DNA or RNA/DNA provided a test of cellular activity. The use of these parameters was based on the work of Boivin ef al. (1948) and Enesco ef al. (1962). Table 2 compares this data in the brain, the liver and the brown adipose tissue.

The number, size and activity of the brain cells did not appear to be modified. The number of cells was notably reduced only in the liver, as shown by the decrease in total DNA in the IUGR rats. The relative proportion of the two cell types present (hepatocytes and erythroblasts) was maintained until birth, then the haematopoetic cells disappeared sooner in the hypoirophic rat, as shown by Larroche ef al. (1971). This process was revealed by a higher weight/DNA ratio in the hypotrophic rat. However, in the brown adipose tissue at birth we observed a decrease in cell number, size and 


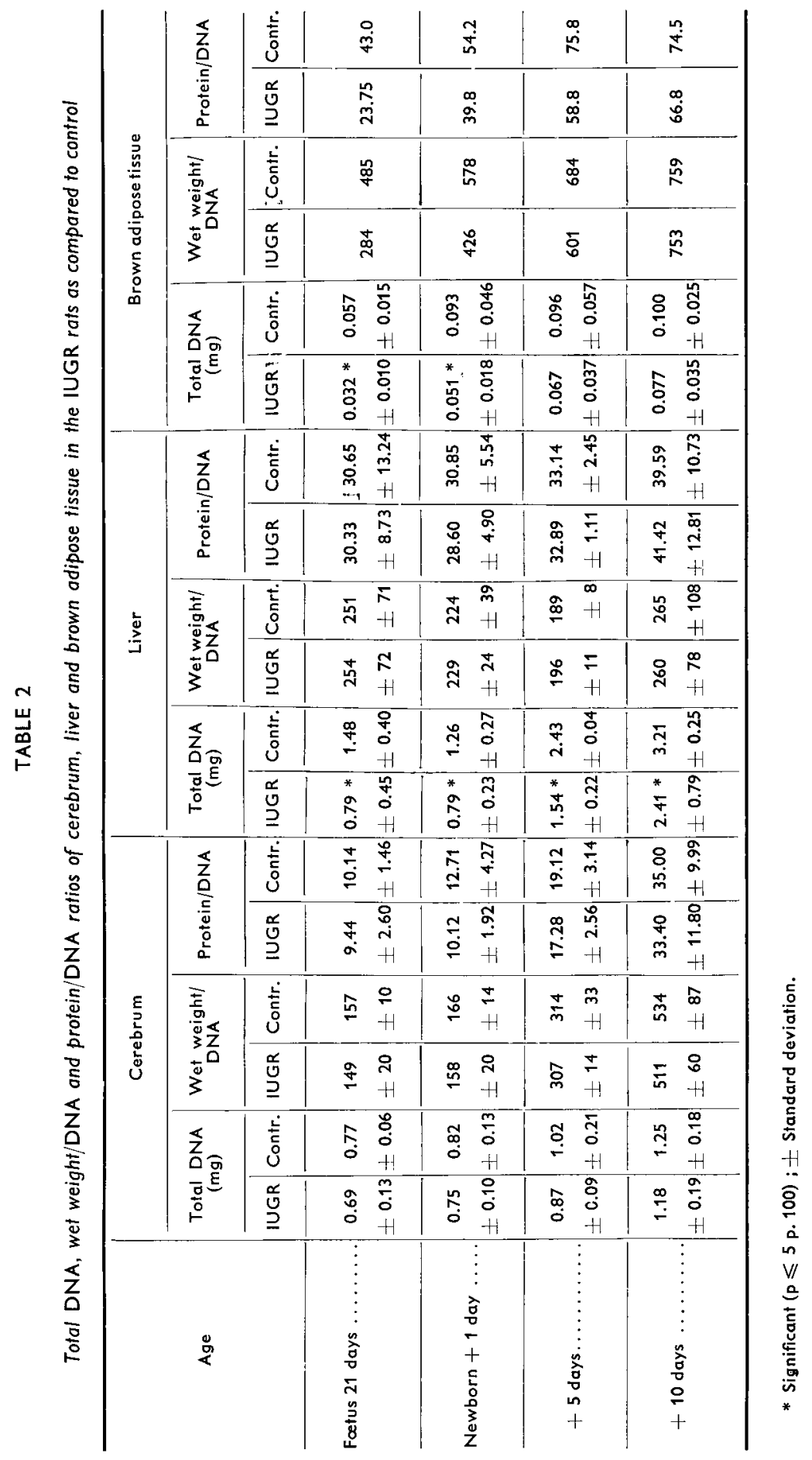


total protein content per nucleus. An alteration of the metabolism in the tissue of hypotrophic animals can therefore be predicted.

B) Cellular multiplication (Roux, 1971b; Roux ef al., 1975). - The hypotrophy of the organs induced by intra-uterine growth retardation appeared to be mostly due to a decrease in cell number. The accumulation of DNA in certain organs was measured parallel to the incorporation of $\mathrm{C}^{14}$ thymidine into the nucleic acid. The study started the day after ligature of the uterine vessels and was continued to postnatal day 5 . In the $24 \mathrm{hrs}$ following the beginning of the experiment, the increase of DNA per organ was appreciably smaller in the liver and lungs of the IUGR than in control animals. The heart and brain showed no modifications. Between days 19 and 20 of gestation the total DNA remained unchanged in the liver of the IUGR subjects, whereas it increased by 30 p. 100 in the controls. In the lungs DNA increment represented only 50 p. 100 of that of the controls. At the same time a decrease of 50 p. 100 was observed in the incorporation of thymidine into these organs. This process is illustroted in the graphs showing the incorporation of thymidine per unit of DNA versus the weight of the organ (fig. 2). However, between days 20 and 21 the process was reversed in the liver, i. e. DNA accumulation was greater in the hypotrophic foetus, and at that moment DNA thymidine incorporation became equal once more to that found in the controls. Similar observations were made in the lungs. In the heart, whose growth is slower at this stage of development, the difference was less noticeable. These results illustrate the changes in organ weight which are observed at birth. The organs most affected in growth retardation were those where maximum growth occurs towards the end of gestation.

After birth a new phase of decreased DNA synthesis was noted. At this point of development the cerebrum and the lungs were unaffected, but the decrease in the growth of the heart became noticeable. This again shows a correlation between the

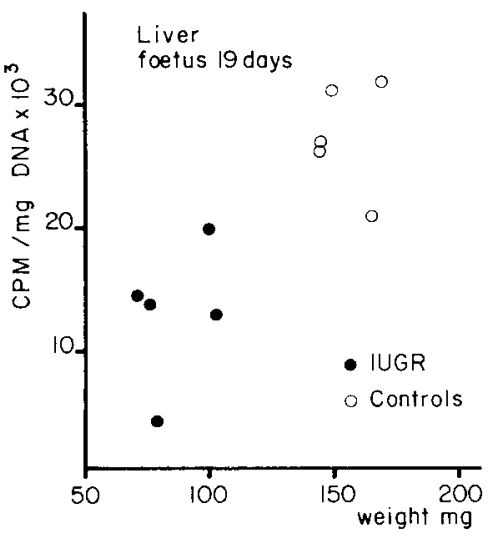

FIG. 2 .

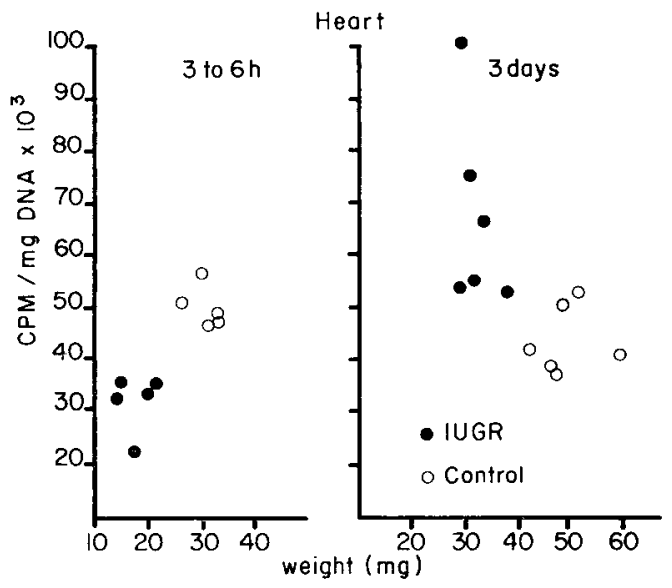

FIG. 3.

FIG. 2. - ${ }^{14} \mathrm{C}$ thymidine incorporation per $\mathrm{mg}$ of DNA as a function of liver weight in the IUGR (๑) and control $(0)$ foetuses at 19 days of gestation.

FIG. 3. $-{ }^{14} \mathrm{C}$ thymidine incorporation per $\mathrm{mg}$ of DNA as a function of heart weight in the IUGR (•) and control (o) newborn ( 6 hrs post-natal and 3 days). 
accumulation of DNA in the organs and the incorporation of ${ }^{14} \mathrm{C}$ thymidine. For example, in the heart the incorporation of thymidine during the first 24 hrs after birth was proportional to the weight of that organ. Later, at 3 days it became inversely proportional to the weight, demonstrating a certain attempt to «catch up 》 in the IUGR newborns (fig. 3). From the biochemical point of view, the decrease in the incorporation of thymidine observed in IUGR organs might be attributed to a diminution in precursor cell penetration. However, this is not the case, for in the acid-soluble fraction containing all the free nucleotides the same label was found in both the IUGR animals and the controls. The incorporation of ${ }^{14} \mathrm{C}$ thymidine could be limited by a deficit of endogenous nucleotides which are essential to DNA synthesis. We found that both the enzymes synthesizing nucleotides by the de novo pathway (carbamyl phosphate synthetase), and those synthesizing by the salvage pathway (uridine kinase) were diminished in the IUGR foetus. Other authors have observed a reduction of DNA polymerase in hypotrophic animals (Jasper et Brasel, 1974). Between days 20 and 21 of gestation uridine kinase activity was stimulated in the liver of the IUGR foetus at the time of thymidine incorporation and DNA increment (table 3). After birth, no changes were found in these liver enzymes (Fulchignoni-Lataud, 1974).

\section{TABLE 3}

Urid ine kinase activity in the liver of IUGR and control rats from 19 days of gestation to $48 \mathrm{hrs}$ postnatally

\begin{tabular}{lccc}
\hline \multicolumn{1}{c}{ Age } & Control & IUGR \\
\hline Fœtus 19 days $\ldots \ldots \ldots \ldots \ldots \ldots \ldots$ & $138.74 \pm 6.21$ & $86.81 \pm 5.33^{*}$ \\
\hline Fœtus 20 days $\ldots \ldots \ldots \ldots \ldots \ldots \ldots$ & $35.97 \pm 4.58$ & $38.44 \pm 6.23$ \\
\hline Fœtus 21 days $\ldots \ldots \ldots \ldots \ldots \ldots \ldots$ & $25.47 \pm 0.88$ & $37.01 \pm 1.71^{*}$ \\
\hline Newborn -6 hours $\ldots \ldots \ldots \ldots \ldots$ & $19.12 \pm 1.87$ & $22.60 \pm 2.03$ \\
\hline Newborn +1 day $\ldots \ldots \ldots \ldots \ldots$ & $26.88 \pm 3.50$ & $25.27 \pm 4.70$ \\
\hline Newborn + - 2 days $\ldots \ldots \ldots \ldots \ldots$ & $37.87 \pm 2.35$ & $39.26 \pm 0.61$ \\
\hline
\end{tabular}

Uridine Kinase activity expressed in $10^{-5} \mu \mathrm{M} U \mathrm{MP} / \mathrm{mg}$ protein $/ \mathrm{min}$.

* Significant ( $p \leqslant 1$ p. 100).

In conclusion a decrease in cellular multiplication was observed, together with a decrease in DNA synthesis during the 2 days following the ligature of the uterine vessels. The effect on the size of the organs depended on their growth rate at this stage of development. A second reduction phase appeared after birth and continued until day 3 . These processes illustrate the somatic growth modification in IUGR rats.

\section{III. - Differentiation of certain biochemical functions.}

The liver and brown adipose tissue were the two organs most affected by the reduction in cell number. Cell size, however, did not appear to be modified in the liver of IUGR rats, although it was lower in the brown adipose tissue. This was also true for 
the RNA/DNA ratio reflecting cell synthesizing capacity. Thus, the processes of cellular differentiation are not affected in the same way in all the organs. At the foetal and neonatal stages, they are characterized by the appearance in the normal animal of certain enzymes whose development coincides with the triggering of hormonal regulations (Greengard, 1971). The effect of a restricted blood flow on the differentiation of several biochemical functions was successively studied in 3 organs : the liver, brown adipose tissue and brain.

\section{A) Liver}

\section{- Glucose metabolism.}

One of the metabolic characteristics of IUGR rats it a severe hypoglycemia which lasts at least until day 10 after birth (fig. 4). Several factors related to the regulation of glycemia were studied in these rats before and after birth.

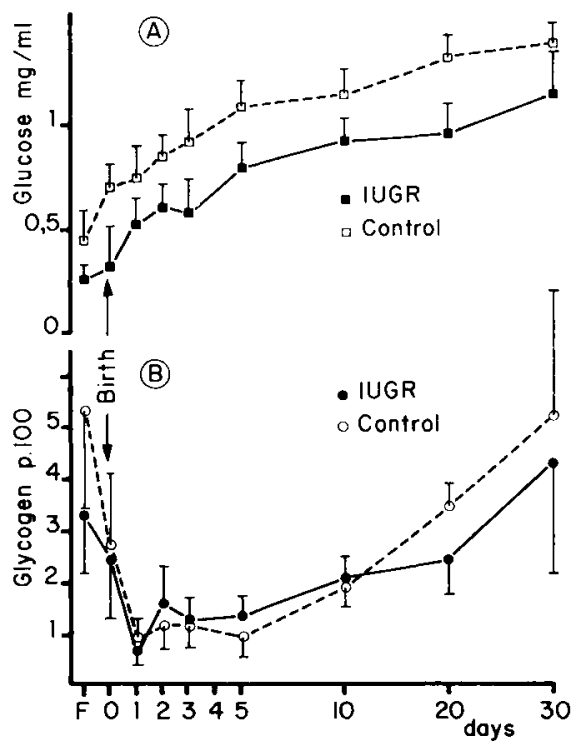

FIG. 4. - Glycemia (A) and glycogen content of the liver (B) during development in IUGR and control rats.

1) Hepatic glycogen stores before and after birth (Chanez et al., 1971). - In IUGR foetuses at 21 days, the level of glycogen was reduced to about 40 p. 100 as compared with that of the control animals. After birth, there was no significant difference in the concentration of glycogen. However, the IUGR newborns only possessed 30 p. 100 of the total glycogen stores of the control animals because of the considerable diminution in the weight of the liver. The decrease in the glycogen concentration before birth probably resulted from a deficient maternal glucose supply due to the restricted blood flow. Glycogen synthesis from glucose did not appear to be disturbed in the IUGR subjects, as was shown by Nitzan and Groffman (1971) in their work on the incorporation of labelled glucose in the glycogen extracted from liver slices. After birth an identical drop in glycogen content was observed in all animals. 
2) Key enzymes in gluconeogenesis. - The gluconeogenesis from lactate, pyruvate and certain amino acids goes through a sequence of irreversible reactions which take different pathways from that of glycolysis. The key enzymes acting in these reactions appear at birth and their activity increases very rapidly in the postnatal period. They are very weak or even imperceptible in the foetus. In IUGR rats we successively measured (Chanez ef al., 1971) glucose-6-phosphatase, fructose 1-6-diphosphatase, and soluble phosphoenol pyruvate carboxykinase which, according to Ballard and Hanson (1967), is the key enzyme initiating the gluconeogenesis sequence after birth. Only the fructose 1-6-diphosphatase showed a slight pause in its development in IUGR, rats 48 hrs after birth (fig. 5). Amino acid gluconeogenesis was assessed by measuring aspartate aminotransferase activity. As before, the enzymatic activity was reduced temporarily at $48 \mathrm{hrs}$ (Tordet-Caridroit, 1971).
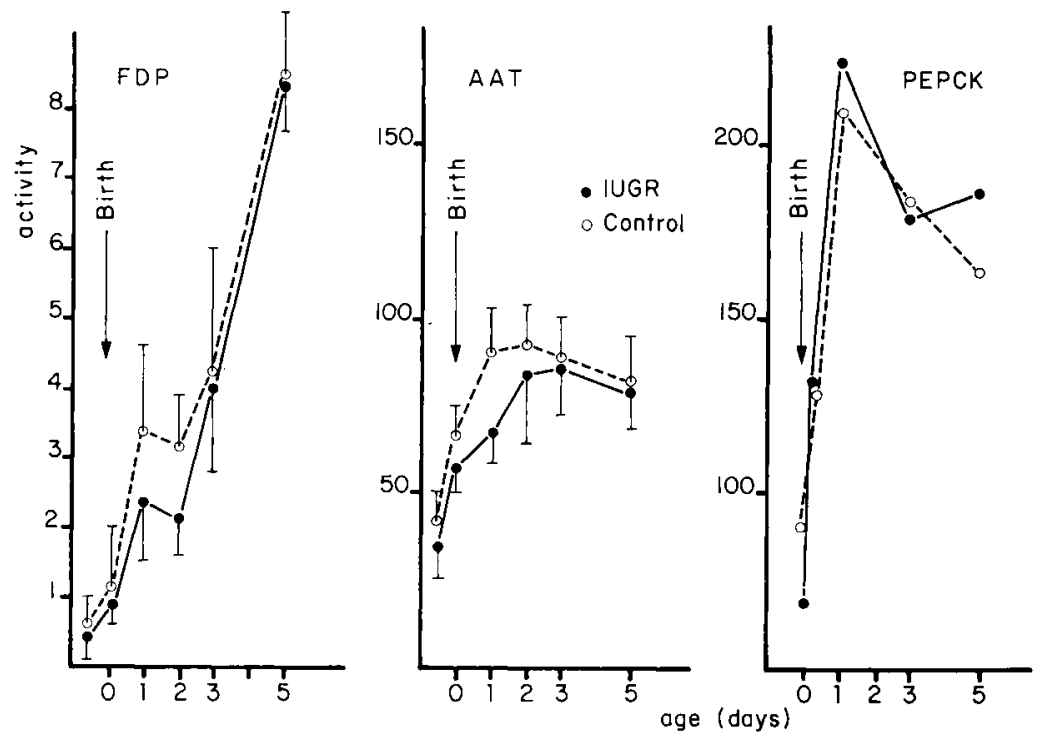

FIG. 5. - Fructose 1-6 diphosphatase, aspartate amino tronsferase and phosphoenol pyruvate carboxikinase activities of the liver during development of IUGR (- - ) and control (---o---) rats.

Hepatic response to hormonal stimuli and measurement of circulating hormones. In the liver of a normal rat the decrease of glucose at birth stimulates secretion of glucagon (Greengard, 1971) which induces the synthesis of tyrosine $\alpha$-ketoglutarate transaminase (TAT) (table 4). The development of TAT was compared in IUGR, control and normal rats (Degremont et al., 1971). The activity of this enzyme was quadrupled in IUGR rats 12 hrs after birth as compared with control or normal rats of the same age. This activity was still higher than that of the controls 5 days after birth. The injection of glucagon into the foetus stimulated induction of TAT, this response being slightly less marked in the IUGR subjects. The injection of glucose $1 \mathrm{hr}$ after birth inhibited induction of the enzyme in both types of animals. These results show that the sequence of events in IUGR rats appears similar to that in the normal animals. Acting 
through hormonal stimuli, the marked diminution of glycemia in IUGR rats triggers increased synthesis of the enzyme. The determinations of circulating hormones carried out by Girard ef al. (1976) in these 2 groups of animals confirm these results. These authors found a higher level of glucagon and a lower level of insulin in IUGR foetuses. The plasma corticosterone level remained unchanged (Chanez-Bel and TordetCaridroit, 1975).

\section{TABLE 4}

Comparison of tyrosine-amino-transferase activity in IUGR and control rats during liver development

\begin{tabular}{lccc}
\hline Age & IUGR & Control & p. 100 of control \\
\hline $\begin{array}{l}\text { Fœtus } \\
n=6\end{array}$ & $0.17 \pm 0.06$ & $0.16 \pm 0.10$ & 0 \\
\hline $\begin{array}{l}6 \text { hours } \\
n=15\end{array}$ & $2.42 \pm 0.58$ & $2.72 \pm 0.56$ & 0 \\
\hline $\begin{array}{l}12 \text { hours } \\
n=6\end{array}$ & $10.60 \pm 0.52$ & $2.34 \pm 0.62$ & 352 \\
\hline $\begin{array}{l}1 \text { day } \\
n=10\end{array}$ & $4.82 \pm 0.88$ & $1.94 \pm 0.28$ & 148 \\
\hline $\begin{array}{l}2 \text { days } \\
n=11\end{array}$ & $4.18 \pm 0.42$ & $2.08 \pm 0.30$ & 100 \\
\hline $\begin{array}{l}3 \text { days } \\
n=8\end{array}$ & $3.60 \pm 0.36$ & $2.34 \pm 0.20$ & 53 \\
\hline $\begin{array}{l}5 \text { days } \\
n=9\end{array}$ & $2.18 \pm 0.52$ & $1.24 \pm 0.10$ & 75 \\
\hline $\begin{array}{l}10 \text { days } \\
n=8\end{array}$ & $1.42 \pm 0.11$ & $1.36 \pm 0.08$ & 4 \\
\hline
\end{tabular}

Activity in $\mu \mathrm{g}$ of PHPP per mg wet weight per min.

4) Glycolytic enzymes. - A study of the development of hepatic lactate dehydrogenase showed no difference between the hypotrophic and the control animals (Chanez ef al., 1971). However, Gali (1976) has noted in the liver and brain of IUGR rats a delay in the maturation of the pyruvate kinase isoenzymes with a persistence in the liver of the foetal form $\left(M_{2}\right.$ type) 6 days after birth.

5) Pentose shunt. - Glucose-6-phosphate dehydrogenase opens the pentose pathway. The consequences of this reaction are firstly the production of reduced coenzymes which are used in the reduction steps of biosynthetic reactions and, secondly, the formation of ribose, the precursor of nucleotide synthesis. The development of this enzyme was not modified by intra-uterine growth retardation. 
- Detoxification function : glutathione-peroxidase (Demus-Oole and Swierczewski, 1969 ; Swierczewski, 1971) (table 5).

\section{TABLE 5}

Development of activity of glutathione-peroxidase in the soluble fraction of normal and IUGR rats. Mean \pm ISD from at least 10 animals. Activity in $\mu$ Moles of $\mathrm{NADPH} / \mathrm{min} / \mathrm{g}$ liver

\begin{tabular}{|c|c|c|c|}
\hline Age & Control & IUGR & $\begin{array}{l}\text { Reduction p. } 100 \\
\text { of control }\end{array}$ \\
\hline 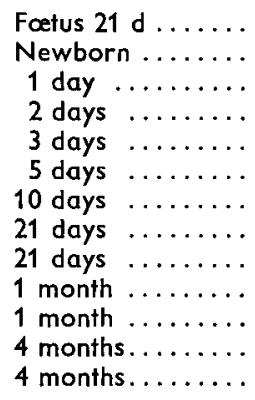 & $\begin{array}{c}7.72 \\
12.42 \pm 2.46 \\
13.26 \pm 2.34 \\
8.92 \pm 1.99 \\
9.98 \pm 1.56 \\
21.50 \pm 3.08 \\
44.90 \pm 7.47 \\
49.08 \pm 10.95 \\
44.02 \pm 8.51 \\
44.50 \pm 10.90^{* *} \\
68.50 \pm 26.50 \\
89.90 \pm 26.00^{* *} \\
188.40 \pm 26.60^{*}\end{array}$ & $\begin{array}{l}5.5(2) * \\
8.0(2) * \\
10.5 \pm 2.5^{* *} \\
7.0 \pm 1.5^{* *} \\
6.5 \pm 1.5^{* *} \\
9.0 \pm 2.5^{* *} \\
24.5 \pm 7.0^{* *} \\
52.5 \pm 12.5 \\
55.3 \pm 11.7 \\
50.0 \pm 10.0 * * \\
70.7 \pm 14.5\end{array}$ & $\begin{array}{l}28 \\
35 \\
20 \\
21 \\
34 \\
58 \\
45\end{array}$ \\
\hline
\end{tabular}

$* \mathrm{n}=2$ in both cases.

** ( $\leqslant 5$ p. 100).

Glutathione-peroxidase, the detoxification enzyme of lipid peroxides, was studied in the liver of normal and IUGR rats during development. This enzyme, mainly found in the liver and the erythrocytes, uses the non-satured fatty acid peroxides as an in vitro substrate. In the normal rat the activity of this enzyme is very low at the end of gestation and increases at birth. From 24 hrs after birth until day 10 its specific activity in IUGR rats was considerably lower. On day 5 this difference reached 58 p. 100 . After day 21 in normal rats there is a sex-linked difference in activity which increases until the 4th month when that of the female is twice that of the male. This sex-linked difference was also observed in IUGR rats without any apparent delay. We showed that the injection of linoleic acid peroxides into the normal rat at the perinatal stage increased hepatic glutathione-peroxidase activity. The delay observed in the synthesis of this enzyme in the liver of the IUGR rats could be due to a decrease or delay in the production of fatty acid peroxides in the tissues. It is possible that IUGR rats, lacking at birth the substrates needed to provide energy, oxidize fatty acids of exogenous and endogenous origin faster, thus preventing the formation of peroxides from these substances.

B) Brown adipose tissue (Cogneville, 1973)

At the neonatal stage and during exposure to cold, the brown adipose tissue (BAT), observed in certain mammals including man, is the principal «effector » of nonshivering chemical thermogenesis. We used the interscapular brown adipose tissue 

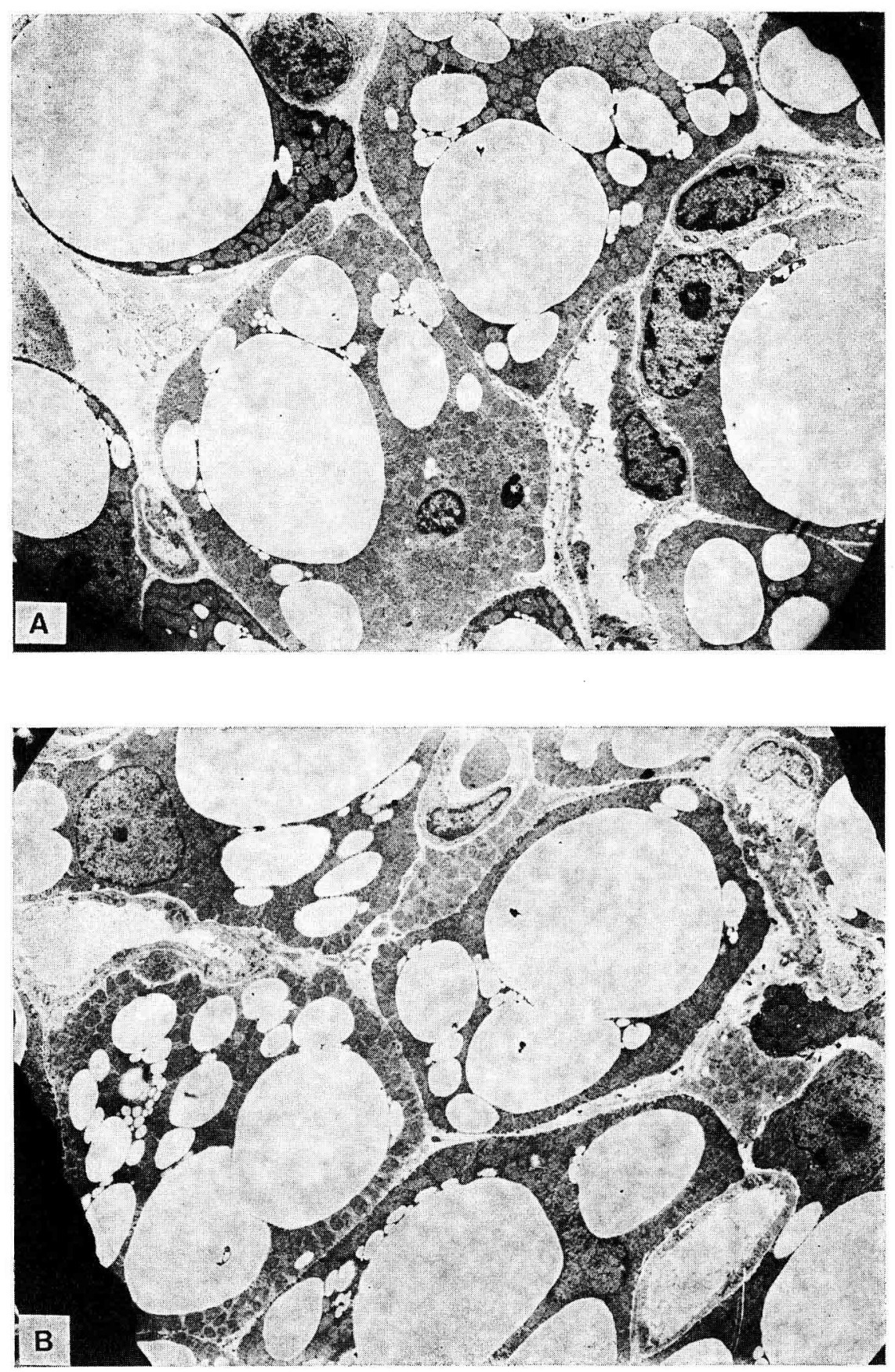

FIG. 6. - Electron micrographs of BAT adipocytes from rats aged 3 days. A) IUGR ; B) Controls. 
(ISBAT) which represents 50 p. 100 of the total brown adipose tissue of the rat. The study was carried out on the foetus from day 1 before birth until day 10 after birth.

1) Morphological study. - The IUGR animals showed a reduction in ISBAT weight during the period studied. ISBAT weight/body weight ratio was lower in IUGR subjects up to 3 days. A correlation is considered to exist between this ratio and animal maturity at birth. It can therefore be postulated that the ISBAT of hypotrophic animals is somewhat immature (Tordet-Caridroit and Cogneville, 1973). The number of ISBAT cells was reduced in IUGR animals and the DNA content was higher than in the controls up to $24 \mathrm{hrs}$ after birth. These results imply a reduction in cell size, which was confirmed by histological study. Under the electron microscope, two types of cells were determined in IUGR subjects. Some were generally found in the ISBAT and were characterized as large, polygonal, and containing several lipidic vccuoles and a large number of mitochondria. The others were smaller, denser and circular. They contained a single lipidic vacuole which, because of its volume, pushed the mitochondria towards the periphery. In these cells there were relatively few mitochondria and the cytoplasm was rich in glycogen (fig. 6). This type of cell was not found in the ISBAT of the control animals. The mitochondria showed no difference either in size or in number of crests.

2) Biochemical study. - A study of the composition of the ISBAT (table 6) revealed differences in lipid and protein contents. No differences were found in the composition of the triglycerides or the phospholipids. The total protein content was lower at 3 days after birth in IUGR rats. The soluble proteins were unmodified, the difference being due to a decrease in mitochondrial proteins. We followed the development of several enzymes important in ISBAT metabolism.

Cytochrome-oxydase : mitochondrial marker enzyme and last stage of the respiratory chain (Cogneville and Tordet-Caridroit, 1974). A significant reduction was observed on day 3 after birth when enzymatic activity was expressed per $g$ of fresh tissue. On the contrary, no difference appeared when the activity was expressed in $\mathrm{mg}$ of mitochondrial protein. These results imply a diminution of mitochondria in the

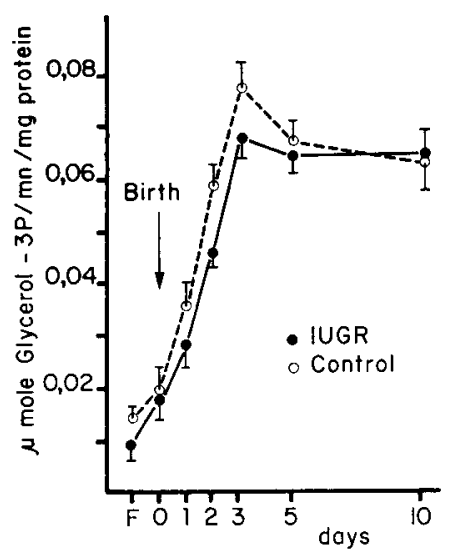

FIG. 7. - Glycerokinase activity in the brown adipose tissue during the development of IUGR $(\longrightarrow-)$ and control (---o---) rats. 
ISBAT cells of the hypotrophic rats. They are comparable to the observations made under the electron microscope.

Glucose-6-phosphate dehydrogenase : supplies the NADPH molecules essential to fatty acid synthesis in the adipose tissue. The specific activity of G-6-PDH was very high in the foetus and fell very rapidly in both types of animals. This is because the rat placenta is barely permeable to fatty acids and the foetus is therefore obliged to synthesize its own lipidic substrates. After birth however, it depends mainly on the exogenous supply (maternal milk). It is interesting to note that up to 5 days this enzyme activity is lower than that of the controls.

Glycerokinase (fig. 7) : allows phosphorylation of glycerol in the presence of ATP. During normal development of the ISBAT, the specific activity of this enzyme (very low at birth) reaches a maximum on day 3 and levels off after day 5. In the IUGR animals, the postnatal evolution of the enzyme was comparable to that of the controls, but the specific activity was significantly lower until day 5 (fig. 7 ).

Despite the significantly decreased activity of these two enzymes on day 3 the IUGR animals had as many, and sometimes more, lipids than the controls. The incorporation of ${ }^{14} \mathrm{C}$ glucose in vivo into the ISBAT lipids was weaker in the IUGR rats until $48 \mathrm{hrs}$; at this stage there was a reversal, and incorporation rose in the hypotrophic animal (Cogneville ef al., 1975). These results are in accordance with the rehabilitation of IUGR lipidic reserves 3 days after birth. In addition this process could partly explain the hypoglycemia observed in the IUGR rats during the neonatal period. During the first days of life the ISBAT of the hypotrophic rat showed a delay in cellular multiplication and in the differentiation of certain enzymes necessary to the functioning of non-shivering thermogenesis. It can therefore be assumed that the hypotrophic animal

TABLE 6

Chemical composition of brown adipose tissue in IUGR and control rats

\begin{tabular}{|c|c|c|c|c|c|c|c|c|}
\hline \multirow[t]{2}{*}{$\begin{array}{c}\text { Age } \\
\text { (days) }\end{array}$} & \multicolumn{2}{|c|}{$\begin{array}{l}\mathrm{H}_{2} \mathrm{O} \\
\text { mg p. } 100 \\
\text { wet weight }\end{array}$} & \multicolumn{2}{|c|}{$\begin{array}{l}\text { Lipids } \\
\text { mg p. } 100 \\
\text { wet weight }\end{array}$} & \multicolumn{2}{|c|}{$\begin{array}{l}\text { Proteins } \\
\text { mg p. } 100 \\
\text { wet weight }\end{array}$} & \multicolumn{2}{|c|}{$\begin{array}{c}\text { DNA } \\
\text { mg p. } 100 \\
\text { wet weight }\end{array}$} \\
\hline & IUGR & Control & IUGR & Control & IUGR & Control & IUGR & Control \\
\hline $\begin{array}{c}\text { Fœtus } \\
21\end{array}$ & $\begin{array}{c}86,66 * * \\
\pm 3,93\end{array}$ & $\begin{array}{l}79,93 \\
\pm \quad 0,26\end{array}$ & $\begin{array}{l}7,41 * * \\
\pm 1,06\end{array}$ & $\begin{array}{c}8,99 \\
+\quad 0,67\end{array}$ & $\begin{array}{c}8,31 \\
\pm \quad 0,99\end{array}$ & $\begin{array}{c}9,12 \\
\pm 0,50\end{array}$ & $\begin{array}{l}0,29 * \\
\pm 0,08\end{array}$ & $\begin{array}{c}0,22 \\
+0,08\end{array}$ \\
\hline $\begin{array}{c}\text { Newborn } \\
1\end{array}$ & $\begin{array}{c}69,49 * * \\
\pm 9,25\end{array}$ & $\begin{array}{c}61,11 \\
\pm 7,73\end{array}$ & $\begin{array}{c}21,38 * * \\
\pm 9,57\end{array}$ & $\begin{array}{l}30,31 \\
\pm 9,61\end{array}$ & $\begin{array}{r}9,69 \\
\pm 0,83\end{array}$ & $\begin{array}{c}9,37 \\
\pm 1,10\end{array}$ & $\begin{array}{c}0,28 * \\
\pm 0,08\end{array}$ & $\begin{array}{c}0,21 \\
+0,07\end{array}$ \\
\hline 3 & $\begin{array}{c}46,32 \\
\pm 6,62\end{array}$ & $\begin{array}{c}45,98 \\
\pm 6,77\end{array}$ & $\begin{array}{r}45,42 \\
\pm 4,65\end{array}$ & $\begin{array}{c}42,11 \\
\pm 7,42 \\
\end{array}$ & $\begin{array}{l}7,81 * \\
\pm 1,20\end{array}$ & $\begin{array}{c}8,63 \\
+\quad 1,43\end{array}$ & $\begin{array}{c}0,22 \\
\pm \quad 0,10\end{array}$ & $\begin{array}{c}0,19 \\
\pm 0,07\end{array}$ \\
\hline 5 & $\begin{array}{r}61,45 \\
\pm 7,81\end{array}$ & $\begin{array}{r}58,68 \\
\pm 5,49\end{array}$ & $\begin{array}{l}26,14 * \\
\pm 7,86\end{array}$ & $\begin{array}{c}30,51 \\
\pm 6,51\end{array}$ & $\begin{array}{c}10,38 \\
\pm 1,66\end{array}$ & $\begin{array}{c}10,44 \\
\pm 1,33\end{array}$ & $\begin{array}{c}0,16 \\
\pm 0,07\end{array}$ & $\begin{array}{c}0,17 \\
+\quad 0,10\end{array}$ \\
\hline 10 & $\begin{array}{c}56,34 \\
\pm 4,50\end{array}$ & $\begin{array}{c}54,15 \\
\pm 7,91\end{array}$ & $\begin{array}{c}29,74 \\
\pm 7,43\end{array}$ & $\begin{array}{l}32,42 \\
\pm 6,94\end{array}$ & $\begin{array}{r}9,25 \\
\pm 2,59\end{array}$ & $\begin{array}{c}9,59 \\
+2,74\end{array}$ & $\begin{array}{c}0,16 \\
\pm 0,07\end{array}$ & $\begin{array}{c}0,14 \\
\pm 0,05\end{array}$ \\
\hline
\end{tabular}

* Significant $(P \leqslant 5$ p. 100); ** Significant $(P \leqslant 1$ p. 100) ; \pm Standard deviation. 
is at a disadvantage when faced with a $\mathrm{n}$ independant life. This would also partly explain the high mortality of these animals during the first days of life, despite normal conditions of temperature and nutrition.

\section{C) Brain}

As already stated, the brain of the IUGR subjects appeared unchanged in terms of weight and cell number. In order to check whether cerebral metabolism was also normal, a few complementary determinations were carried out on the lipidic composition related to myelinisation.

a) Total phospholipids. - No difference in the evolution of phospholipids was observed between the IUGR and control rats. The composition of fatty acids in the phospholipids also remained the same after birth. In the foetus the percentage of arachidonic acid was lower. This temporary difference was also found in the desaturation of linoleic acid, an indispensable fatty acid and the sole precursor of arachidonic ccid. Soon after birth the IUGR animals had the same percentage as the controls (ValletStrouve and Tordet-Caridroit, 1976).

b) Cerebrosides. - Cerebrosides characterize myelin lipids. At the age of 21 days they appeared in both the IUGR and the control rats.

c) Cholesterol. - The concentration of cholesterol doubled between days 5 and 21 . but the evolution was identical in both groups.

\section{Discussion and conclusion.}

All cells need a balanced supply of substrates. It cannot yet be determined whether a restriction of any one of these substrates plays a role in the differentiation of pluricellular organisms, but the rapid response of microorganisms and cells in culture to modifications of the environmental composition suggests that this may be the case. The main events marking growth are cellular proliferation, and the processes of differentiation and cellular interactions. During the development of a normal organism each of these events takes place according to a genetically determined program and is of strictly limited duration. When an adult animal is subjected to nutritional restriction the differentiated organism responds by mobilizing its stores and reducing its needs. In biochemical terms this means a diminution of proteic synthesis and cell size (liver, fat). During gestation, the foetus depends essentially on the maternal supply. If metabolite flow is restricted, it can only survive by reducing its proteic synthesis and rate of cellular multiplication as it has no reserves of its own. In our experimental model, each organ responded to restricted blood flow according to its own particular stage of development. We noticed especially that all the organs but the brain, responded by a deceleration of cellular multiplication; this was very marked as the cells were in a stage of rapid proliferation. The processes of differentiation are not seriously disturbed in the hypotrophic animal. For example, the enzymes appear normally, but the amount synthesized is sometimes smaller. The synthesis of the same enzyme (G-6-PDH) may be modified in one organ (BAT) and remain normal in another (liver). We noted that 
ligature on day 17 of gestation causes two series of events. The first occurs immediately after the prenatal operation, the second just after birth. Postnatal disturbances are of two sorts : those of short duration (up to 5 days maximum), i. e. decrease of DNA synthesis and that of certain specific proteins; and others lasting longer (sometimes until weaning), i. e. hypoglycemia and hyperalaninemia. As far as hypoglycemia is concerned, the only factors which can explain its persistence are unequal weight of brain weight of body ratio and possibly a higher utilisation of glucose in the tissues of the hypotrophic. This study proves the extreme complexity of the experimental model. Each process needs a model which is easier to interpret, as for example cells in culture. The interplay of regulations throughout the organism obscurs primary response to one experimental procedure which at first may seem simple and limited in time.

4e Réunion du groupe Développement I.N.R.A., Montpellier, 17-18 mai 1978.

Résumé. Un retard de croissance intrautérine a été provoqué par le blocage de l'artère utérine le $17 \mathrm{e}$ jour de la gestation. La diminution du poids du corps, ainsi que de celui de différents organes dépend uniquement d'une réduction du nombre des cellules, à l'exception du tissu adipeux brun où, à la fois sont réduits le nombre et la taille des cellules. Dans chaque organe les changements observés dans l'incorporation de thymidine ${ }^{14} \mathrm{C}$ dans l'ADN sont en corrélation positive avec l'aug mentation de l'ADN et le taux de croissance. Une étude des processus de différenciation biochimiques fut effectuée sur le foie (enzymes clés de la gluconéogenèse, glycolyse et détoxification), le cerveau (composition lipidique en relation avecla myélinisation) et le tissu adipeux brun (protéines mitochondriales, lipides, glycérokinase). Les activités enzymatiques apparaissent normalement, mais quelquefois la quantité d'enzymes synthétisée est plus faible. Une caractéristique frappante est le maintien du poids du cerveau et du nombre de ses cellules à un niveau normal.

\section{References}

ANDREWS B. F., 1970. Symposium on the small for date infant. The Pediatric clinics of North America W. B. Saunders Company, Philadelphia, Vol. 17, $n^{0} 1$.

BALLARD F. J., HANSON R. W., 1967. Phosphoenol pyruvate carboxykinase and pyruvate carboxylase in developing rat liver. Biochem. J., 104, 866-871.

BOIVIN A., VENDRELY R., VENDRELY C., 1948. L'acide désoxyribonucléique du noyau cellulaire dépositaire des caractères héréditaires : arguments analytiques. C. R. Acad. Sci., Paris, 226, $1051-1053$.

CHANEZ C., ROUX J. M., TORDET-CARIDROIT C., 1969. Glycémie, glycogène et glucose-6-phosphatase dans le foie à la période périnatale chez le rat dysmature. C. R. Soc. Biol., 163, 2272. 2274.

CHANEZ C., TORDET-CARIDROIT C., ROUX J. M., 1971. Studies on experimental hypotrophy in the rat. II. - Development of some live r enzymes of gluconeogenesis. Biol. Neonate, 18, 56-65.

CHANEZ-BEL C., 1972. Retard de croissance intra-utérine chez le rat. Recherches allométriques ef métaboliques. Thèse de Doct. ès Sci., Univ. Paris VI.

CHANEZ-BEL C., TORDET-CARIDROIT C., 1975. Influence du retard de croissance intra-utérine sur le taux de corticostérone plasmatique et surrénalien chez le rat au cours du développement. C. R. Acad. Sci. Paris, Sér. D, 169, 286-290.

COGNEVILLE A. M., 1973. Etude de quelques aspects du métabolisme lipidique du tissu adipeux brun interscapulaire du rat hypotrophique au cours du développement. Thèse Doct. $3^{\mathrm{e}}$ cycle, Paris Sud Orsay.

COGNEVILLE A. M., TORDET-CARIDROIT C., 1974. Developmental patterns of glycerokinase and cytochrome-c-oxidase in the brown adipose tissue of hypotrophic rats. Biomedicine, 21, 323326. 
COGNEVILLE A. M., CIVIDINO N., TORDET-CARIDROIT C., 1975. Lipid composition of brown adipose tissue as related to nutrition during the neonatal period in hypotrophic rat. $J$. Nutr., 105, $982-988$.

DEGREMONT C., ROUX J. M., SWIERCZEWSKI E., TORDET-CARIDROIT C., 1971. Tyrosine $\alpha$ ketoglutarate transaminase in the liver of rats with intra-uterine growth retardation. Life Sci. 10, 1115-1123.

DEMUS-OOLE A. M., SWIERCZEWSKI E., 1969. Glutathione peroxidase in rat liver during development. II. - Changes in glutathione peroxidase during post-natal development of normal and hypotrophic rats. Biol. Neonate, 14, 219-225.

ENESCO M., LEBOND C. P., 1962. Increase in cell number as a factor in the growth of the organs and tissues of the young male rat. J. Embryol. exp. Morphol., 10, 530-562.

FULCHIGNONI-LATAUD M. C., 1974. L'uridine kinase : relation de son activité avec la croissance des organes du rat. Thèse Doct. $3^{\mathrm{e}}$ cycle, Univ. Paris Vl.

GALI P., 1976. The isoenzymes of pyruvate kinase in normal hypothyroid and dysmature rats. Biomedicine, 25, 268-272.

GIRARD J. R., CHANEZ C., KERVRAN A., TORDET-CARIDROIT C., ASSAN R., 1976. Studies on experimental hypotrophy in the rat. III. - Plasma-insulin and glucagon. Biol. Neonate, 29, 262-266.

GREENGARD O., 1971. Enzymic differentiation in mammalian tissues. In CAMPBELL P. N., DICKENS F., Essays in biochemistry, Vol. 7, 159-205, Acad. Press N. Y.

JASPER H. G., BRASEL Jo. A., 1974. Effects of varied nutritional rehabilitation on DNA synthesis. 14e Pediatr. Congr. int. 118-129. Ed. Med. Panam. S A, Buenos-Aires, Argentine.

LARROCHE J. C., HERISSARD N., BENNOUN M., 1971. Hepatic hematopoiesis in hypotrophic rats. Comparison to growth-retarded infants. Biol. Neonate, 18, 279-289.

NITZAN M., GROFFMAN H., 1971. Glucose metabolism in experimental intra-uterine growth retardation, in vitro studies with liver and brain slices. Biol. Neonate, 17, 420-426.

ROUX J. M., TORDET-CARIDROIT C., CHANEZ C., 1970. Studies on experimental hypotrophy in the rat. I. - Chemical composition of the total body and some organs in the rat foetus. Biol. Neonate, 15, 342-347.

ROUX J. M., 1971. Studies on cellular development in the suckling rat with intra-uterine growth retardation. Biol. Neonate, 18, 290-299.

ROUX J. M., 1971b. Decrease in the rate of the desoxyribonucleic acid synthesis in newborn rats with intra-uterine growth retardation. Biol. Neonate, 18, 463-467.

ROUX J. M., JAHCHAN T., FULCHIGNONI M. C., 1975. Desoxyribonucleic acid and pyrimidine synthesis in the rat during intra-uterine growth retardation : responsiveness of several organs. Biol. Neonote, 27, 129-140.

SWIERCZEWSKI E., 1971. Glutathion peroxidase. Thèse Doct. ès Sciences, Université Paris VII.

TORDET-CARIDROIT C., ROUX J. M., CHANEZ C., 1969. Etude du développement postnatal du rat né dysmature. C. R. Soc. Biol. 163, 1321-1322.

TORDET-CARIDROIT C., 1971. Evolution périnatale de l'aspartate-amino-transférase hépatique chez le rat ayant subi un ralentissement de croissance intra-utérine. Ann. Biol. anim. Bioch. Biophys., 11, 389-397.

TORDET-CARIDROIT C., COGNEVILLE A. M., 1973. Developmental changes in intra-uterine growth retardation of rat interscapular brown adipose tissue, 18-22. In VAGUE J., BOYER J., The regulation of the adipose tissue mass. Excerpta Med., Amsterdam.

VALLET-STROUVE C., TORDET-CARIDROIT C., 1973. Desaturation of linoleic acid in the liver and brain during the development of rats with intra-uterine growth retardation. Biol. Neonate, 23, 446-455.

WIGGLESWORTH J. S., 1964. Experimental growth retardation in the foetal rat. J. Path. Bact., 88, $1-33$.

WINICK M., 1974. Nutrition and foetal development. Wiley and Sons N. Y., Vol. 2. 